\title{
Analysis of medium earthquake design for super high-rise buildings
}

\author{
HUANG LING
}

\author{
College of Civil Engineering and Architecture, Nanchang Hangkong University, Nanchang
}

KEYWORD: transfinite structure ;elasticity level under medium earthquake; un-yielding level under medium earthquake

ABSTRACT: In recent years, the complex high-rise buildings are increasing. The complex structure and transfinite structure often need to adopt the medium earthquake design. This paper first introduces the concept and design method of the medium earthquake design. Then,take a taransfinite frame shear wall structure as an example. The key points of the medium earthquake design are presented under the current specifications and design conditions and some design proposal in seismic design were given, which can give reference for seismic design.

\section{INTRODUCTION}

In China ,the "three levels, two stage" seismic design methods were applied in seismic design .The completeing of the first level seismic fortification goal and the third level seismic fortification goal was by the design under the first and the second stage respectively. To accomplish the second level seismic fortification goal mainly by details of seismic design rather than quantitative performance level. The span of the frequent earthquake and rare earthquake is relatively large take the exceeding probability into consideration in China. The structure did not achieve performance levels under common earthquake and rare earthquake which designed according to the requirements of frequent earthquake design. Besides, it also can not meet the multi-failure criteria goal.Now, some designers only pay attention to the calculation of seismic bearing capacity requirements of structural members, ignoring the seismic performance of the overall structure, especially the yield failure mechanism under medium earthquakes.In order to balance the complex transfinite high-rise structure design's safety and economical efficiency, the structure calculation and analysis of seismc performance under medium earthquake were needed.In other words, to seismic design taking whole structure, key parts and key components as object under medium earthquake.

\section{PROJECT SUMMARY}

\section{The basic information of structure}

The RC frame-core structural system is used for this 43 floors building. The structure storey height is $4 \mathrm{~m}$ and the total height is $483 \mathrm{~m}$. The standard layer planar graph is shown in figure 1 . The shear-wall tube structure consist of building electricity (floor) ladder, equipment tube Wells and public service area. The core tube plane size is $14.95 \mathrm{~m} \mathrm{x17.45} \mathrm{m}$. The thickness of the core tube external wall decreases from 700 to $400 \mathrm{~mm}$, the thickness of the core tube internal wall gradually decreased to $300 / 250 \mathrm{~mm}$ by $300 \mathrm{~mm}$. Area outside the core tube area floor planes are hotel and office. Outer frame column spacing can be adapted to the building space requirements which the minimum spacing 6.8 meters, the maximum 13.0 meters. The section at the bottom of the frame column decreases from $1100 \times 1100 \mathrm{~mm} / 1000 \times 2200 \mathrm{~mm}$ to $900 \times 900 \mathrm{~mm} / 900 \times 1500 \mathrm{~mm}$. This project floor effective width is less than $50 \%$ and openings area is greater than $30 \%$. The structure one to three layers have the layer column, the roof frame column transformation which make it belongs to the irregular plane structure. The structure adopted the following performance goal in seismic design:

The reinforced part at the bottom of core tube shear wall and the bottom part of the frame column strengthened were by elastic design. The non reinforced part at the bottom of core tube shear wall and the non strengthen part at the bottom part of the frame column design conformed to small bending yield, shear not yield. Energy dissipation components such as coupling beam and frame beam in part of bending yield, shear not yield design. At the bottom PKPM was used to establish a calculation model which is a engineering software developed by China construction science research institute. The model is shown in figure 2. 


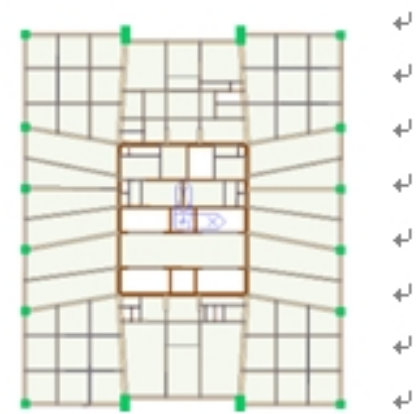

Figure 1 The standard layer planar graph

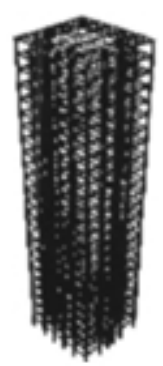

Figure 2 PKPM model

\section{Load information}

The floor dead load is $6.5 \mathrm{k} \mathrm{N} / \mathrm{m} 2$, Roof dead load is $7.5 \mathrm{k} \mathrm{N} / \mathrm{m} 2$, commercial floor live load is $3.5 \mathrm{k} \mathrm{N} / \mathrm{m} 2$, the office floor live load is $2.5 \mathrm{k} \mathrm{N} / \mathrm{m} 2$ and the dead load between beam is $1.5 \mathrm{k} \mathrm{N} / \mathrm{m} 2$ considering the glass curtain wall's load. Seismic information:the intensity of an earthquake resistance of building is 6 , group one, basic acceleration magnitude of design is $0.05 \mathrm{~g}$, the construction sites is the medium soft soil, construction site classification II, design feature period is $0.35 \mathrm{~s}$. Wind load information : the basic wind pressure is $0.3 \mathrm{k} \mathrm{N} / \mathrm{m} 2$ and the ground roughness class is of B class.

\section{Seismic analysis of fortification intensity}

The stage of elastic design and un-yield design under medium earthquake are the same. That is to say, to seismic design according to the basic seismic intensity. The influence coefficient's maximum value of horizontal earthquake in accordance with the basic earthquake intensity level which is about 2.85 times than the value under small earthquake by the response spectrum method. The components'stress state of elastic design and un-yield design under medium earthquake are the same.But the the safety of structure design is different. The un-yield design under medium earthquake does not consider the partial load factor. The value of material strength is standard value. Regardless of the bearing capacity coefficient of seismic adjustment coefficient and adjustment coefficient of internal force. SATWE's main input parameters can be found in the table below:

\section{THE MAIN ANALYSIS RESULTS OF MODEL}

\section{structure displacement response}

\begin{tabular}{|c|c|c|c|}
\hline \multicolumn{2}{|c|}{ Displacement index.1 } & $\begin{array}{c}\text { medium earthquake elastic. } \\
\text { un-yeld analysis.r }\end{array}$ & $\begin{array}{c}\text { medium earthquake control } \\
\text { targets. }\end{array}$ \\
\hline \multirow{2}{*}{$\begin{array}{c}\text { Maximal } \\
\text { inter-laminar } \\
\text { displacement angle. }\end{array}$} & \begin{tabular}{|c|}
$\mathrm{X}$ \\
direction. \\
\end{tabular} & $1 / 501(33 F)$. & \multirow{2}{*}{$1 / 400}$. \\
\hline & $\begin{array}{c}\mathrm{Y} \\
\text { direction. }\end{array}$ & $1 / 575(28 \mathrm{~F})$ & \\
\hline \multirow{2}{*}{$\begin{array}{l}\text { The ratio of maximal } \\
\text { displacement and } \\
\text { average displacement. }\end{array}$} & $\begin{array}{c}\mathrm{X} \\
\text { direction }\end{array}$ & $1.19(1 F)$ & \multirow{2}{*}{$\begin{array}{c}\text { Considering the influence of } \\
\text { accidental eccentricity, } \\
\text { Should not be greater than } \\
1.2 \text { and can not be greater } \\
\text { than } 1.2 \ldots\end{array}$} \\
\hline & $\begin{array}{c}\mathrm{Y} \\
\text { direction. }\end{array}$ & $1.13(1 F)$ & \\
\hline
\end{tabular}


Structure displacement response between the layers

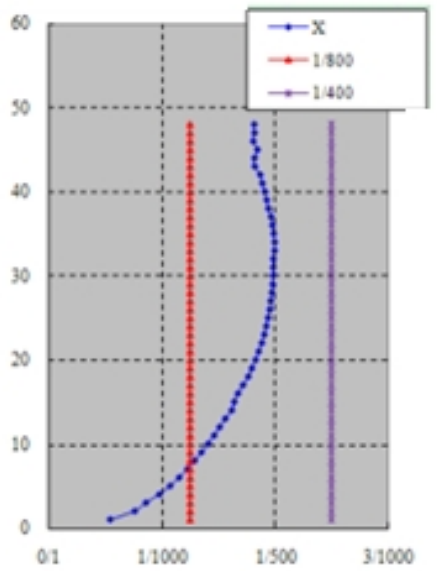

Figure 3 inter-laminar displacement angle in $\mathrm{X}$ direction

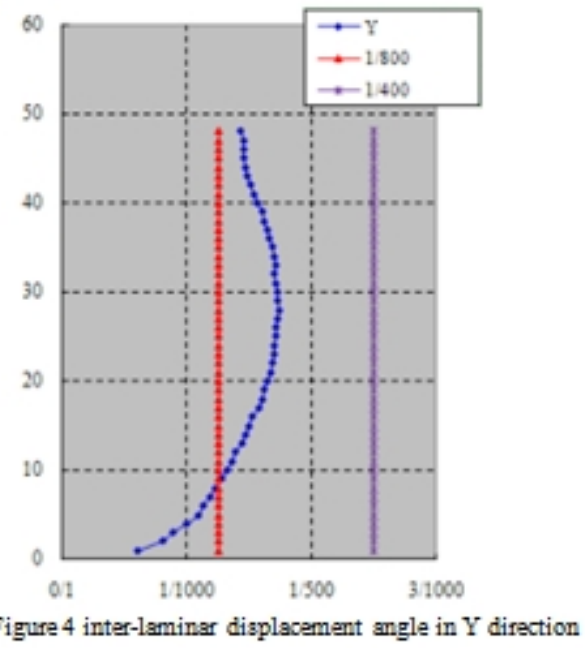

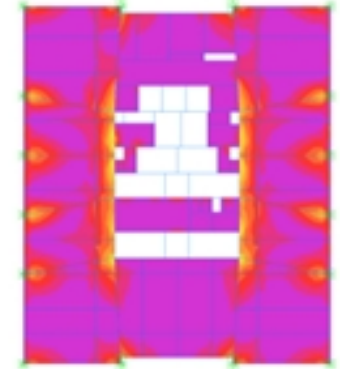

Figure 56 floor $\mathrm{X}$ direction 0 degrees earthquake nomal stress

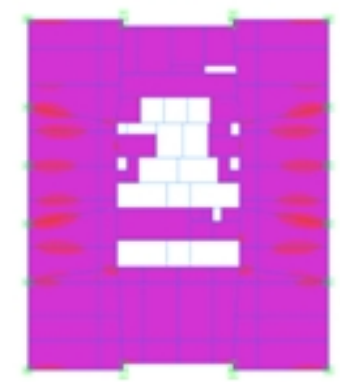

Figure 66 floor $Y$ direction 0 degrees. earthquake nomal stress.।

The figure shows structure layer displacement can satisfy the requirements of control target under medium seismic. 


\begin{tabular}{|c|c|c|c|}
\hline \multicolumn{2}{|r|}{ project. } & medium earthquake elastic & medium earthquake \\
\hline \multirow{10}{*}{$\begin{array}{c}\text { analysis } \\
\text { conditions } \\
\end{array}$} & Floor plate models., & elastic floor. & elastic floor. \\
\hline & $\alpha_{\max }$ & 0.139. & 0.139 \\
\hline & TE, & 0.35. & 0.35. \\
\hline & $\begin{array}{l}\text { Earthquake internal } \\
\text { force adjustment } \\
\text { coefficient. }\end{array}$ & 1.0. & 1.0. \\
\hline & $\begin{array}{c}\text { partial coefficient for } \\
\text { action.. }\end{array}$ & $\begin{array}{l}\text { The same as small } \\
\text { earthquake analysis.t }\end{array}$ & 1.0. \\
\hline & $\begin{array}{l}\text { material partial } \\
\text { coefficient. }\end{array}$ & $\begin{array}{l}\text { The same as small } \\
\text { earthquake analysis. }\end{array}$ & 1.0. \\
\hline & $\begin{array}{l}\text { seismic bearing capacity } \\
\text { adjustment coefficient. }\end{array}$ & $\begin{array}{l}\text { The same as small } \\
\text { earthquake analysis.t }\end{array}$ & 1.0 .1 \\
\hline & Material strength. & Using design value.. & Using standard.r. \\
\hline & $\begin{array}{c}\text { Coupling beam stiffness } \\
\text { reduction. }\end{array}$ & 0.5 & 0.5 \\
\hline & $\begin{array}{l}\text { If includeded in the } \\
\text { wind load effect.r }\end{array}$ & Not included. & Not included. \\
\hline$\therefore$ & Other parameters. & $\begin{array}{l}\text { The same as small } \\
\text { earthquake analysis. }\end{array}$ & $\begin{array}{l}\text { The same as small } \\
\text { earthquake analysis. }\end{array}$ \\
\hline
\end{tabular}

\section{Internal force analysis results of earthquake action of fortification intensity}

The analysis result of frame beam, column, coupling beam and shear wall can satisfy the requirements of control target under fortification intensity earthquake.

\section{The finite element analysis of slab under the fortification intensity earthquake}

The six layer of the building is hotel typical standard.and the fifteen layer is the hotel compound upper level. It has many opening holes. The thirty layer of the building is office typical standard. And the maximal inter-laminar displacement angle reached the maximum in the thirty layers. The fortyfour layer is a large roof layer and the outer frame column in the conversion layer. Considering the floor slab may cause a large surface deformation under horizontal load, the finite element analysis of six layers, fifteen layers, thirty layers and forty-four floors in accordance with the elastic plate which ensure the floor slab does not appear penetrating crack in the elastic analysis.Software ETABS was used to analysis the stress Stress of elastic floor slab. Analysis using shell element to simulate elastic slab. Take the sixth layer as an example, the $\mathrm{X}$ and $\mathrm{Y}$ direction of in-plane stress graph as follows:

\begin{tabular}{|c|c|c|c|c|}
\hline \multicolumn{2}{|c|}{ Internal force index. } & $\begin{array}{c}\text { medium } \\
\text { earthquake elastic }\end{array}$ & $\begin{array}{l}\text { medium earthquake } \\
\text { un-yeld elastic }\end{array}$ & $\begin{array}{l}\text { The base shear } \\
\text { ratio of medium }\end{array}$ \\
\hline \multirow{2}{*}{$\begin{array}{l}\text { Total basal } \\
\text { shear }(\mathrm{kN})\end{array}$} & $\mathrm{X}$ direction. & \multicolumn{2}{|c|}{23137.} & 2.96. \\
\hline & $\mathrm{Y}$ direction. & \multicolumn{2}{|c|}{23076.} & 2.94. \\
\hline \multirow{2}{*}{$\begin{array}{c}\text { Total base } \\
\text { bending } \\
\text { moment } \\
\text { (KN.m) }\end{array}$} & $\mathrm{X}$ direction. & \multicolumn{2}{|c|}{2552294.1} & $\therefore$ \\
\hline & $\mathrm{Y}$ direction. & \multicolumn{2}{|c|}{2667968.} &. \\
\hline \multirow{2}{*}{$\begin{array}{l}\text { Maximum } \\
\text { axial } \\
\text { compression } \\
\text { ratio. }\end{array}$} & $\begin{array}{l}\text { Core shear } \\
\text { wall. }\end{array}$ & 0.57. & 0.57 &. \\
\hline & $\begin{array}{c}\text { outside frame } \\
\text { column. }\end{array}$ & 0.90 & 0.58 & . \\
\hline
\end{tabular}

The figure shows: The normal stress in most area of the floor slab is small under medium earthquake and less than concrete tensile strength standard values. Only in the elevator well opening hole and the surrounding structure of tension plate has a greater concentration of stress. The area most located in the width of the wall or frame beam which stress exceeding the standard value of tensile strength of concrete. Other areas are less than the standard value of tensile strength of concrete. So we concluded that the floor surface did not produce penetrating crack. The floor has a great stress concentration on the floor opening periphery and core tube aisle wall limb edge. The area most located in the wall width range which stress exceeding the standard value of tensile strength of concrete. Other areas are less than the standard value of tensile strength of concrete. The design will be based on the results of the calculation of the core range of the floor slab with double two-way reinforcement which can ensure the reinforcement in the concrete floor will not reach the yield strength under medium earthquake. There are large stresses in the partial column joints and the beam edges. Because the out-of-plane bending beams to make local deformation occurring at the junction of the floor slab, forming stress concentration. 


\section{conclusion}

Base on above analysis, under fortification intensity earthquake action; (1)structure vertical members are in elastic state. Frame column axial compression ratio and the conc rete compression stress of core sheer wall all can meet the requirement of seismic fortification under fortification intensity earthquake action.In order to meet "strong shearing and weak bending "concept design require-

ment, , as to coupling beam with excessive shear force, adding cross hidden bracing should be consid ered when design。 Strengthening the thickness of floor with large stress, double layer and double di rec-

tion reinforce should be designed to ensure steel in concrete slab can not reach yield strength under moderate earthquake.

(2)Unyield design under moderate earthquake is considered as carrying capacity limited condition in mod-

erate earthquake elastic design, the seismic requirements of moderate earthquake elastic design are st ric-

ter and safety stocks are more larger Moreover, moderate earthquake design is designed without con sider-

ing internal force adjustment coefficient, the internal force under moderate earthquake design is likely to be smaller than internal force under small earthquake elastic design when the seismic intensity of $\mathrm{c}$ omponent is high,especially unyield design under moderate earthquake. So the structure design should not only focus on the earthquake calculation results but also envelope design.

(3) Structural stiffness degradation, the value of earthquake influence coefficient of complex and new building, structural damping ratio value, seismic design theory, national standards and calculation software under medium earthquake need to be further perfected.

\section{Reference:}

[1] Unified standard for reliability designof building structuresG B 50068-2011

[2] Code for seismic design of buildingsGB 50011-2012

[3] SATWE user manual and technical condition

[4] Code for design of concrete structures GB 50010-2010

[5] Xu Peifu. Complex high-rise building structure design. China building industry press, 2005. 